\title{
Effect of rainfall events on soil carbon flux in mountain pastures
}

Seok-Hee Jeong ${ }^{1}$, Ji-Young Eom', Jae-ho Lee ${ }^{2}$ and Jae-Seok Lee ${ }^{1 *}$ (D)

\begin{abstract}
Background: Large-scale land-use change is being caused by various socioeconomic problems. Land-use change is necessarily accompanied by changes in the regional carbon balance in terrestrial ecosystems and affects climate change. Therefore, it is crucial to understand the correlation between environmental factors altered by land-use change and the carbon balance. To address this issue, we studied the characteristics of soil carbon flux and soil moisture content related to rainfall events in mountain pastures converted from deciduous forest in Korea.

Results: The average soil moisture contents (SMC) during the study period were $23.1 \%$ in the soil respiration (SR) plot and 25.2\% in the heterotrophic respiration (HR) plot. The average SMC was increased to 2.1 and $1.1 \%$ in the SR and HR plots after rainfall events, respectively. In addition, saturated water content was $29.36 \%$ in this grassland. The soil water content was saturated under the consistent rainfall of more than $5 \mathrm{~mm} \mathrm{~h}^{-1}$ rather than short-term heavy rainfall event. The average SR was increased to $28.4 \%$ after a rainfall event, but the average HR was decreased to 70 . $1 \%$. The correlation between soil carbon flux rates and rainfall was lower than other environmental factors. The correlation between SMC and soil carbon flux rates was low. However, HR exhibited a tendency to be decreased when SMC was $24.5 \%$. In addition, the correlation between soil temperature and respiration rate was significant.

Conclusions: In a mountain pasture ecosystem, rainfall induced the important change of soil moisture content related to respiration in soil. SR and HR were very sensitive to change of SMC in soil surface layer about 0-10-cm depth. SR was increased by elevation of SMC due to a rainfall event, and the result was assumed from maintaining moderate soil moisture content for respiration in microorganism and plant root. However, HR was decreased in long-time saturated condition of soil moisture content. Root has obviously contributed to high respiration in heavy rainfall, but it was affected to quick depression in respiration under low rainfall. The difference of SMC due to rainfall event was causative of a highly fluctuated soil respiration rate in the same soil temperature condition. Therefore, rainfall factor or SMC are to be considered in predicting the soil carbon flux of grassland ecosystems for future climate change.
\end{abstract}

Keywords: Mountain pasutres, Soil respiration, Heterotrophic respiration, Rainfall, Soil moisture content

\section{Background}

In the carbon cycle in terrestrial ecosystems, carbon is fixed by photosynthesis from the atmosphere, and the fixed carbon is returned to the atmosphere by the respiration of plants (autotrophic respiration (AR)), although some is absorbed into the soil. The carbon is stored in the soil, and it is released back into the atmosphere by soil respiration (SR), which includes plant root respiration (RR) and heterotrophic respiration (HR) (Hanson et al. 2000). The carbon cycle is a common process in terrestrial ecosystems;

\footnotetext{
* Correspondence: jaeseok@konkuk.ac.kr

${ }^{1}$ Department of Biological Science, Konkuk University, Seoul, South Korea

Full list of author information is available at the end of the article
}

however, the amount and speed of carbon cycling are distinct in ecosystems. In addition, the combination of characteristics that constitute distinct climatic areas, such as boreal, temperate, and tropical, and vegetative characteristics, such as annuals, perennial herbaceous, shrubs, and trees, occasion various ecosystems. These terrestrial ecosystems have different carbon cycling characteristics, and it is necessary to understand the carbon cycle process of various ecosystems to quantify it.

Forest ecosystems are a very important part in the global carbon cycle. The study of carbon cycling in forest ecosystems has resulted in the accumulation of a variety of data, and it is still being studied by many 
researchers (Musselman and Fox 1991, Dixon et al. 1994, Ohashi et al. 2000, Xu et al. 2015). However, forests are rapidly changing to grasslands and agricultural lands for economic purposes in various regions (Goldewijk 2001, Foley et al. 2005). In addition, this trend is expected to continue. As a result, these changes will affect regional carbon cycle and the global carbon cycle (Houghton 1999). Therefore, it is very important to collect and understand carbon cycle data based on changes in land-use patterns.

Although forests have been converted into various forms in the mid-latitudes of Asia, the form that contributes the most to the ecosystem carbon cycle and achieves most economic objectives is the grassland. In addition, grassland ecosystems, which cover $25 \%$ of the total land area (Meyer and Turner 1994), are a very important part of the carbon cycle (Scurlock and Hal 1998). In addition, carbon accumulation in grasslands accounts for over $10 \%$ of that of all terrestrial ecosystems (Eswaran et al. 1993, Nosberger et al. 2000).

The grassland ecosystem has a different carbon cycle from that of the forest ecosystem because of new aboveground plant growth each year. The grassland ecosystem is dominated by herbaceous plants with no canopy. Thus, the grassland ecosystem is strongly affected by changes in temperature and soil moisture content caused by sunlight and rainfall (White et al. 2000). Therefore, the instability of the ecosystem is higher than that of the forest ecosystem because of the extreme changes caused by weather events, such as drought and heavy rain. The instability caused by climate change in the grassland ecosystem influences vegetation, which eventually affects the carbon cycling in the ecosystem (Haas et al. 1957, Cole et al. 1989). In addition, the total area of grassland is increasing because of social and economic problems (Lambin and Meyfroidt 2011). Without understanding the quantitative and qualitative characterization of cycling carbon in the grassland ecosystem, it will be difficult to understand and predict the global carbon cycle.

To understand the carbon cycle of the grassland ecosystem, it is necessary to understand soil carbon cycles because $98 \%$ of total carbon in grasslands is accumulated in the soil (Hungate et al. 1997). Soil carbon flux is very important in the soil carbon cycle, which is correlated with various environmental factors, such as air temperature, soil temperature, soil moisture, and vegetation (Raich and Schlesinger 1992, Davidson et al. 1998). In the soil carbon cycle, precipitation patterns, such as annual rainfall, total precipitation, and strength of rainfall, affect soil carbon flux (Sala and Lauenroth 1982, Lauenroth and Bradford 2009). A 0-5-cm depth of soil is the area with the highest soil microbial abundance and organic carbon (Parton et al. 1987) because rainfall leads to rapid soil carbon flux when there is high soil moisture content (Birch 1958, Sponseller 2007). This occurs because the soil microorganism activity promotes the decomposition of organic carbon from the soil (Bottner 1985). In addition, carbon flux occurs because of the reduction of soil porosity by abiotic processes (Huxman et al. 2004). Therefore, for the quantitative and qualitative assessment of the carbon cycle of the grassland ecosystems, it is crucial to understand the correlation between environmental factors, such as changes in precipitation and soil moisture content.

In this study, we attempt to understand the carbon cycle of mountain pastures where temperate deciduous forests dominated by Quercus were converted to pasture. Additionally, we clarified the relationship between soil carbon flux and soil moisture content associated with rainfall events. Thus, we analyzed the relationship between soil carbon flux and changes soil moisture content based on total precipitation, hourly precipitation, and precipitation duration in grassland ecosystems.

\section{Methods}

\section{Site description}

Our study was conducted in mountain pastures in Daegwallyeong, Gangwon Province ( $37^{\circ} 68^{\prime} 52^{\prime \prime} \mathrm{N}, 128^{\circ} 73^{\prime}$ $47^{\prime \prime}$ E) in Korea. The study site is a mountain pasture where the study was conducted in 1956 . Originally, the area was a temperate forest dominated by Quercus genus such as Quercus mongolica. The mountain pasture was dominated by Poa pratensis and Festuca ovina. Other common species included Artemisia princeps and Rumex acetosella. The site was at an altitude of $840 \mathrm{~m}$, the average annual temperature for the last 30 years (19812010) was $6.6{ }^{\circ} \mathrm{C}$, and the average annual rainfall was $1989 \mathrm{~mm}$ (Climatological Normals of Korea 2011). This study site is located in the temperate northern climate zone and middle province of floristics (Noh et al. 2013). Therefore, this is included in an alpine area with an average temperature of about $6{ }^{\circ} \mathrm{C}$, lower than that of the lowlands, and about 135 days frostless period (Han and Kim 1993).

\section{Measurement of environmental factor}

Precipitation was measured in an open area to accurately determine the moisture in the ecosystem. Precipitation was collected with a $0.2-\mathrm{mm}$ rain gauge (S-RGB-M002, Onset, USA), and data were sampled every minute and recorded at 30-min intervals with a data logger ( $\mathrm{HOBO}$ micro station, Onset, USA).

Soil moisture content was measured at a point within $30 \mathrm{~cm}$ of the SR and HR measurement points to minimize spatial non-uniformity of soil and carbon flux. 
The soil moisture content was measured from 0 - to $15-\mathrm{cm}$ depth using a water content reflectometer (CS616, Campbell Scientific, USA). The soil temperature was measured at 5-cm depth with a T-type thermocouple $(0.32-\mathrm{mm}$ diameter, Suzuden, Japan). Data consisted of a measurement every $10 \mathrm{~s}$, and data were recorded every 2 min by the data logger (CR1000, Campbell Scientific, USA).

\section{Measurement of soil carbon flux}

Measurement plot of $15 \mathrm{~m} \times 10 \mathrm{~m}$ was installed in mountain pasture plots. And area of $7 \mathrm{~m} \times 1 \mathrm{~m}$ was selected for measuring soil respiration and three chambers were installed. Also, three trenched plots were set near the soil respiration measurement plot about $1 \mathrm{~m}$ away from, and three heterotrophic respiration measurement chambers were installed. We used the applied automatic opening and closing chamber (AOCC) system (Suh et al. 2006) based on open-flow method to measure soil carbon flux. The AOCC system was consisted of three parts: chamber, pump, and controller. The chamber has a motor for regulating the opening and closing of the chamber. The chambers were designed to be $9.5 \mathrm{~cm}$ above the ground. Six chambers for three SR and three HR were installed in the soil carbon flux measurement plot, which automatically opened and closed sequentially for $10 \mathrm{~min}$. The pump circulated the air in the closed circuit space. In a closed dynamic chamber (CDC) method, carbon dioxide $\left(\mathrm{CO}_{2}\right)$ concentration in the closed space is measured by IRGA (Li-840, Li-Cor. USA). To calculate $\mathrm{SR}$ and $\mathrm{HR}$, raw data of $\mathrm{CO}_{2}$ concentration were collected every $2 \mathrm{~min}$ by the data logger (CR1000, Campbell Scientific, Logan, UT). ncreasing rates of $\mathrm{CO}_{2}$ concentration per unit time were calculated. And these variables were used to calculate the soil carbon release rate based on

$$
\mathrm{SR}\left(\mathrm{mg} \mathrm{CO} \mathrm{CO}^{-2} \mathrm{~h}^{-1}\right)=a \rho V A^{-1}
$$

where $a$ is the $\mathrm{CO}_{2}$ rate of increase $\left(\mathrm{ppm} \min ^{-1}\right), \rho$ is the $\mathrm{CO}_{2}$ density $\left(\mathrm{mg} \mathrm{m}^{-3}\right), V$ is the chamber volume $\left(\mathrm{m}^{3}\right)$, and $S$ is the soil area $\left(\mathrm{m}^{2}\right)$.

\section{Results and discussion}

Rainfall and soil moisture contents

Eight rainfall events consisting of a single rainfall event of $5 \mathrm{~mm}$ and more were selected during the study period. The changes in hourly precipitation, soil moisture content, and soil carbon flux were investigated for a total of $51 \mathrm{~h}$, including $6 \mathrm{~h}$ before rainfall events. In addition, some data were lost because of heavy rain or lightning during the study period. The lost data were estimated using the temperature data from the Daegwallyeong weather station and the exponential correlation between temperature and the soil carbon flux.

The grassland is in a mountainous area at $840 \mathrm{~m}$ above sea level. Approximately 50\% of the annual rainfall is concentrated in the summer as is typical of temperate northern climates. The study period lasted a total of 123 days from July 2015 to October 2015. During the study period, there were a total of 54 rain days, and total precipitation was $481.8 \mathrm{~mm}$. August had the highest rainfall of $313.9 \mathrm{~mm}$, and rainfall was 72.6, 32.4, and $63.0 \mathrm{~mm}$ in September, July, and October, respectively (Fig. 1). Rainfall during July-August was $376.9 \mathrm{~mm}$ and accounted for $78.2 \%$ of total rainfall during the study period. Average monthly precipitation during the study period for the last 30 years (1981-2010) at the study site was 326.7, 420.9, 307.3, and $124.9 \mathrm{~mm}$ for July, August,

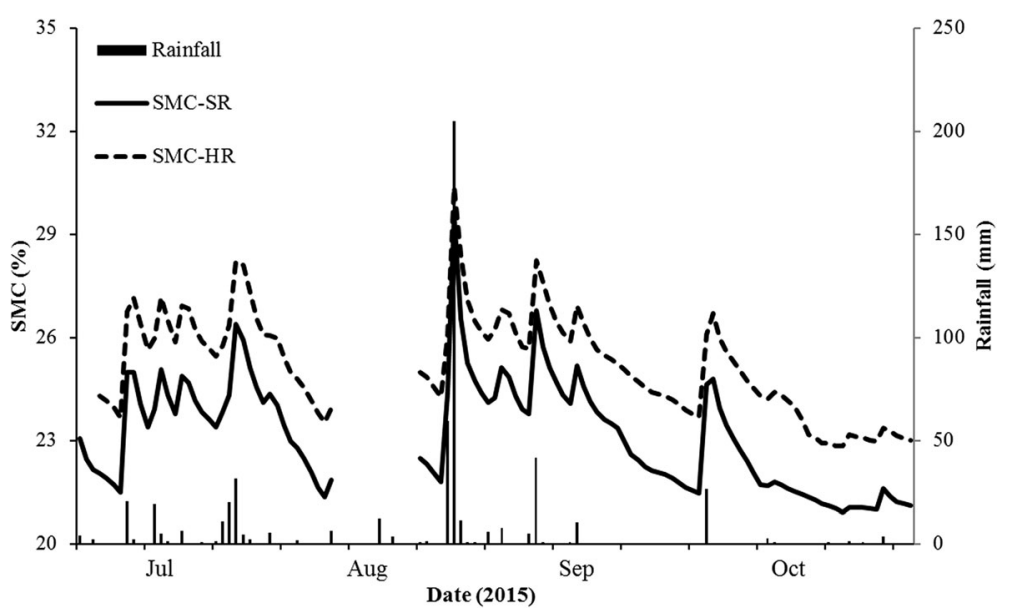

Fig. 1 Variation of soil moisture content in soil respiration measurement plot (SMC-SR) and soil moisture content in heterotrophic respiration measurement plot (SMC-HR) and rainfall during the study period in an artificial alpine grassland in Daegwallyeong 
Table 1 Monthly precipitation and soil moisture content (SMC) in soil respiration (SR) and heterotrophic respiration (HR) measurement plot during the study period

\begin{tabular}{|c|c|c|c|c|c|c|c|c|}
\hline & \multicolumn{2}{|l|}{ July } & \multicolumn{2}{|c|}{ August } & \multicolumn{2}{|c|}{ September } & \multicolumn{2}{|c|}{ October } \\
\hline & $S R$ & $\mathrm{HR}$ & SR & $\mathrm{HR}$ & $S R$ & $\mathrm{HR}$ & SR & $\mathrm{HR}$ \\
\hline SMC (\%) & 23.9 & 26.1 & 23.5 & 25.5 & 23.5 & 25.5 & 21.8 & 23.9 \\
\hline Rainfall (mm) & 135.6 & & 308.2 & & 65.7 & & 35.5 & \\
\hline
\end{tabular}

September, and October, respectively (Climatological Normals of Korea, 2011). The amount of precipitation and rain days during the study period compared to average precipitation in mountainous grassland was lower than normal.

The soil moisture content was $23.1 \%$ in the SR and $25.2 \%$ in the HR plot, and the HR plot exhibited an average $2.1 \%$ higher than the SR plot during the entire study period (Table 1). Eight rainfall events with a single rainfall of more than $5 \mathrm{~mm}$ were selected during the study period. We determined hourly precipitation and soil moisture content of the SR and HR plot for a total of $51 \mathrm{~h}$, including $6 \mathrm{~h}$ before the rainfall events. The critical rainfall amount for soil moisture changes appeared to be $5 \mathrm{~mm}$. The average soil moisture content before the rainfall event was $23.6 \%$ in the SR plot and $25.0 \%$ in HR plot; thus, it was $1.4 \%$ higher in the HR plot. The average soil moisture content after the rainfall event increased by 2.1 and $1.1 \%$, respectively, and was $25.7 \%$ for the SR plot and $26.1 \%$ for the HR plot (Fig. 2). Soil moisture content increased immediately after the rainfall event when the rainfall amount per hour was $8.4 \mathrm{~mm}$, and soil moisture content increased to $29.36 \%$ in both the SR and HR plots. Thus, the saturation point for soil water in the grassland was 29.36\% (Fig. 2f). In addition, heavy and continuous precipitation was needed for precipitation per hour to reach the highest soil moisture content (Fig. 2f, h). At 11:00 in Fig. 2f, the soil moisture content reached $29.36 \%$ at $8.4 \mathrm{~mm} \mathrm{~h}^{-1}$ of precipitation. However, at 13:00 in Fig. $2 \mathrm{~h}$, the soil moisture content at $7.4 \mathrm{~mm} \mathrm{~h}$ ${ }^{-1}$ was $27.74 \%$. Thus, total precipitation was $50.4 \mathrm{~mm}$ for Fig. 2f, but only $24.8 \mathrm{~mm}$ for Fig. 2h, and total precipitation affected the saturation point for soil moisture content. The average soil moisture content of the 0-30-cm depth of soil measured in the Chinese Loess Plateau (Chen et al. 2008) was $14.6 \%$, but the average soil moisture content at this study site was $24.6 \%$. Fay et al. (2003) reported that average soil moisture content was $17 \%$ and increased by $40-50 \%$ during a rainfall event. However, there appeared to be differences in climate and soil quality.

\section{Soil moisture content and soil carbon flux based on rainfall patterns}

The average SR during the study period from July to October was $307.3 \mathrm{mg} \mathrm{CO} \mathrm{m}^{-2} \mathrm{~h}^{-1}$, and average HR was $224.5 \mathrm{mg} \mathrm{CO} \mathrm{m}^{-2} \mathrm{~h}^{-1}$. Monthly average for SR from July to October were 428.7, 382.9, 274.1, and 142.4 mg $\mathrm{CO}_{2} \mathrm{~m}^{-2} \mathrm{~h}^{-1}$ and for $\mathrm{HR}$ were 272.2, 296.9, 211.5, and $117.1 \mathrm{mg} \mathrm{CO} \mathrm{m}^{-2} \mathrm{~h}^{-1}$, respectively (Fig. 3). Total average HR accounted for $73 \%$ of the total average SR. The soil carbon flux was shown the typical seasonal

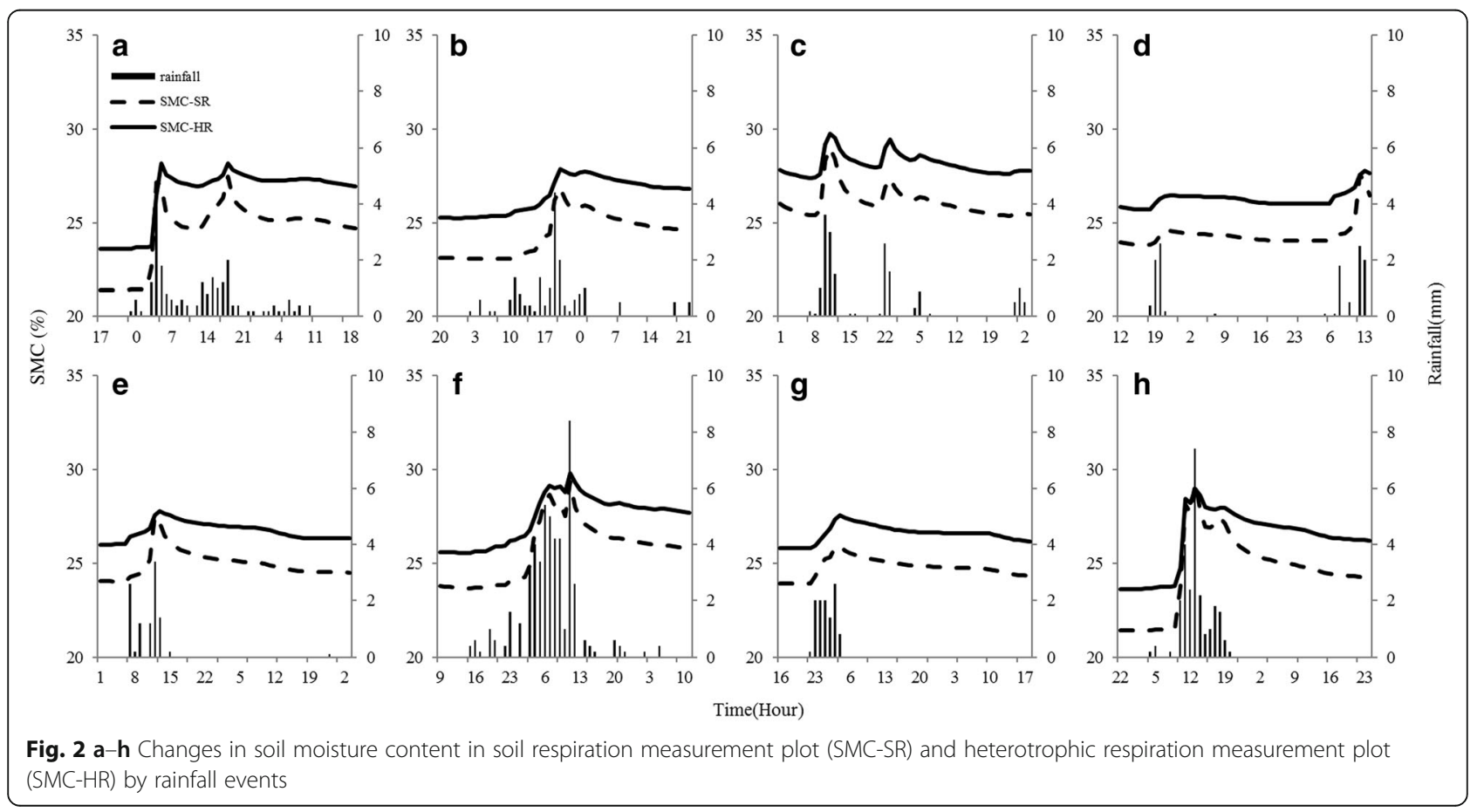




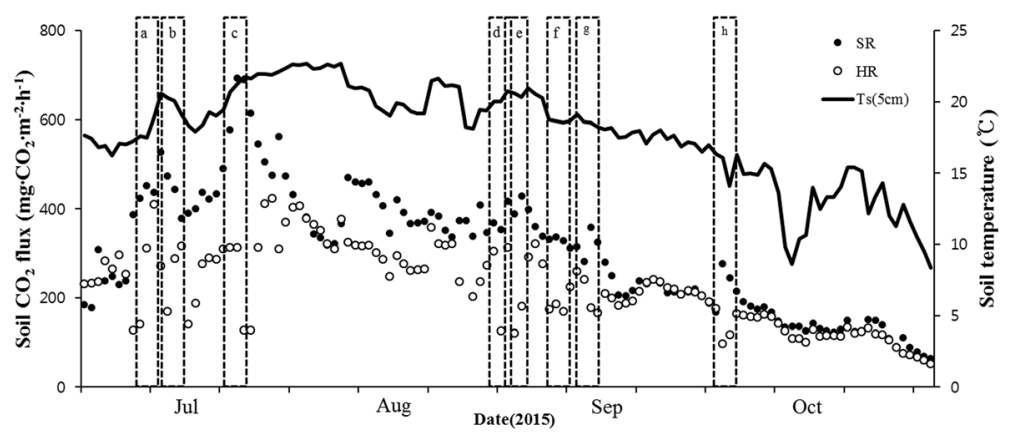

Fig. 3 Changes in soil respiration (SR), heterotrophic respiration (HR), and soil temperature (Ts, $5-\mathrm{cm}$ depth) during the study period. Also, we chose eight rainfall events $(a, b, c, d, e, f, g, h)$ with a single rainfall of more than $5 \mathrm{~mm}$ during the study period

variation, with the highest flux during the high temperatures in July and August. However, the soil carbon flux pattern was changed by rainfall events. SR was increased during rainfall, whereas HR was decreased.

Changes in soil carbon flux because of rainfall events in the grassland ecosystem could be roughly divided into three stages after the rainfall event. The first stage is the process in which $\mathrm{CO}_{2}$ in soil pores is released by rainwater immediately after rainfall (Liu et al. 2002). In addition, $\mathrm{CO}_{2}$ dissolved in the rain is released as it collides with the ground (Lee et al. 2004). The second stage is an increase in soil microorganism activity that occurs for several hours to several days after the rainfall event. The dry environment is not conducive to soil microbial activity; however, the rainfall events increase the humidity in the soil environment. Humid soil conditions increase soil microbial activity (Gliński and Stępniewski 1985, Steenwerth et al. 2005). Increased soil microbial activity leads to increased soil respiration. The third stage occurs up to 7 days after the rainfall event. In this stage, the substrate is activated and plant root activity was increased. Thus, soil microbial respiration (Huxman et al. 2004) and root respiration increase (Huang and Nobel 1993). Through these stages, rainfall events increase soil carbon flux.

Increased soil moisture content caused by the rainfall events changed the SR and HR (Fig. 4). The average SR before the rainfall event was $289.3 \mathrm{mg} \mathrm{CO} \mathrm{m}^{-2} \mathrm{~h}^{-1}$, whereas the SR immediately after the rainfall was increased in five of the eight rainfall events and decreased in three events (Fig. 4). In addition, the average SR increased by $28.4 \%$. However, average HR was $216.8 \mathrm{mg} \mathrm{CO}_{2} \mathrm{~m}^{-2} \mathrm{~h}^{-1}$ before a rainfall event and $101.2 \mathrm{mg} \mathrm{CO}_{2} \mathrm{~m}^{-2} \mathrm{~h}^{-1}$ after an event. HR decreased by up to $89.2 \%$ and average decrease was $70.1 \%$ after seven rainfall events (Fig. 4).

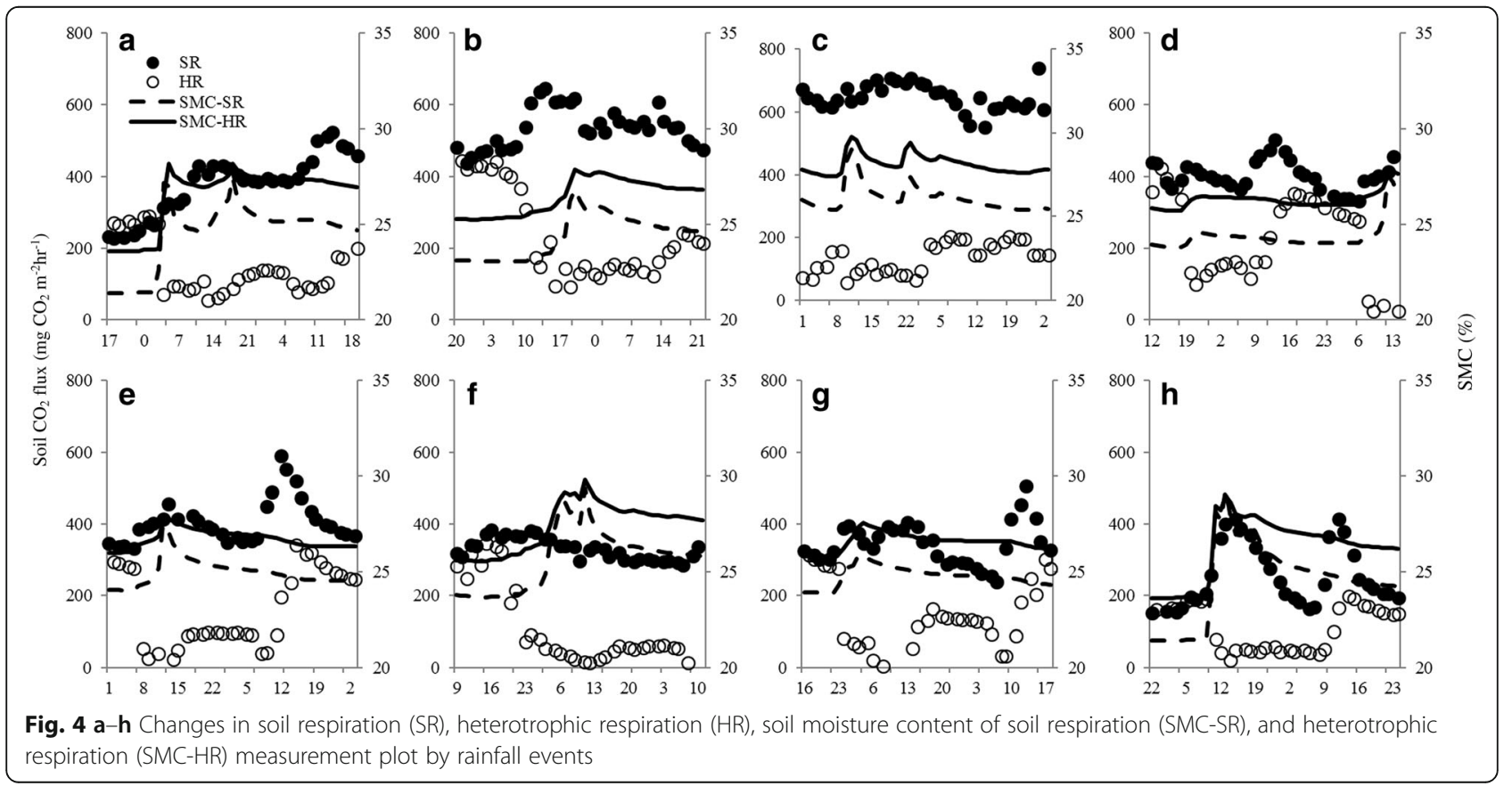


Rainfall events appeared to immediately increase SR because rainwater collide with the ground and the soil porosity decreases, releasing the $\mathrm{CO}_{2}$. However, $\mathrm{HR}$ sharply declined during precipitation. This was caused by the rapid increase in soil moisture content and lack of oxygen in the soil. Reduced oxygen in soil pores inhibited the activity of soil microorganisms (Stark and Firestone 1995). According to a study by Suseela et al. (2012), the optimum soil moisture content for HR is $15-26 \%$, and a soil moisture content of more than $26 \%$ inhibits soil microbial activity by forming a thin film of water on soil particles (Skopp et al. 1990, Yiqi and Zhou 2010). These results indicated that the optimum soil moisture content was $24.5 \%$, which is similar to the results of this study (Fig. 5a).

\section{Relationship between soil carbon flux and environmental factors}

Soil carbon flux was closely related to environmental factors other than rainfall and soil moisture content. Various soil physicochemical properties, such as vegetation and topography characteristics (Tamai 2010), and climatic factors, such as soil temperature, air temperature, photons, and humidity (Raich and Schlesinger 1992), affect carbon accumulation in the litter layer and soil (Trumbore 2000). In particular, soil temperature is important for the activity

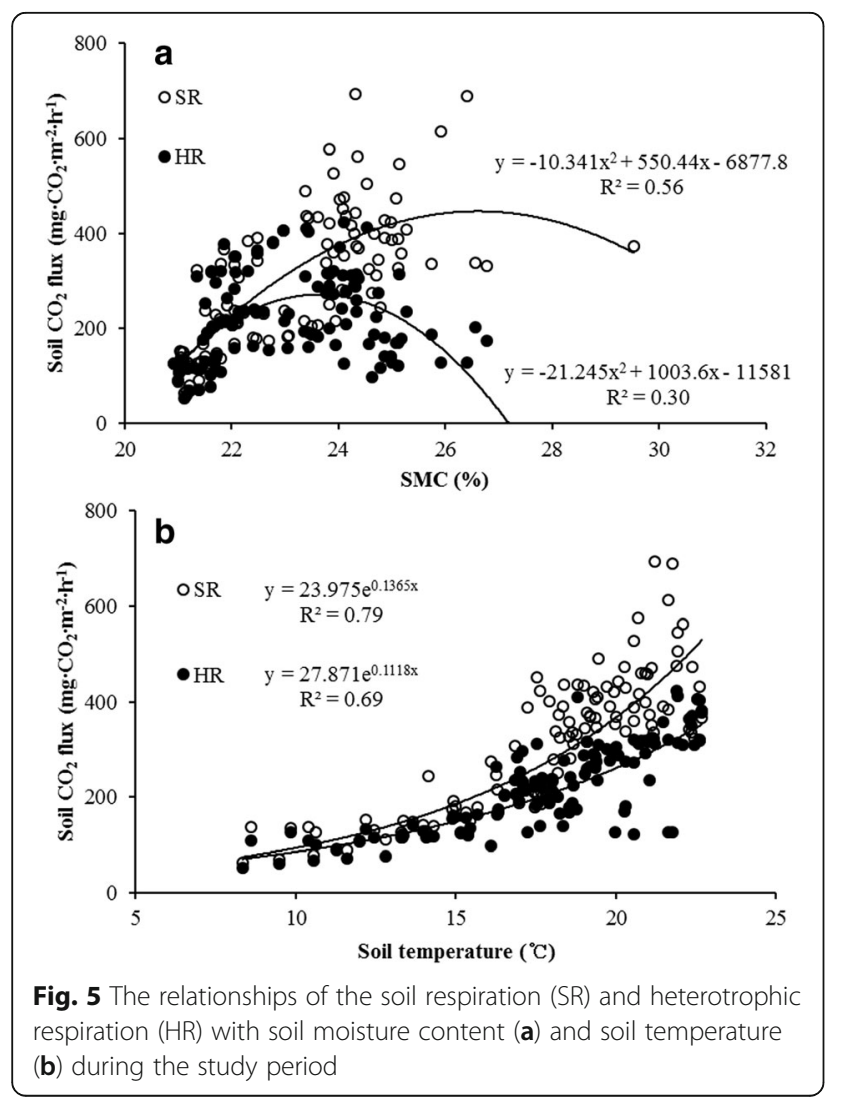

of vegetation and soil microorganisms and thereby affects the soil carbon flux.

Correlation analysis was performed to understand the relationships between soil carbon flux and hourly precipitation, soil moisture content, and soil temperature during rainfall events. The correlation between hourly rainfall and SR was low (Fig. 6a). The correlation between soil moisture content and SR was also low $\left(R^{2}=0147\right)$, but HR exhibited a tendency to decrease with soil moisture content of $24.5 \%$ $\left(R^{2}=0.5451\right)$ (Fig. 6b). This result indicated that SR was not correlated with soil moisture content during the rainfall event, whereas HR was significantly correlated (Figs. 5a and 6a). In addition, the correlation between soil carbon flux and soil temperature at $5-\mathrm{cm}$ depth was significantly correlated with SR $\left(R^{2}=0.8046\right)$, whereas HR did not exhibit any significant relationship (Fig. 6c). However, the correlation between soil temperature and soil carbon flux during the entire survey period (Fig. $5 \mathrm{a}$ ), including before and after
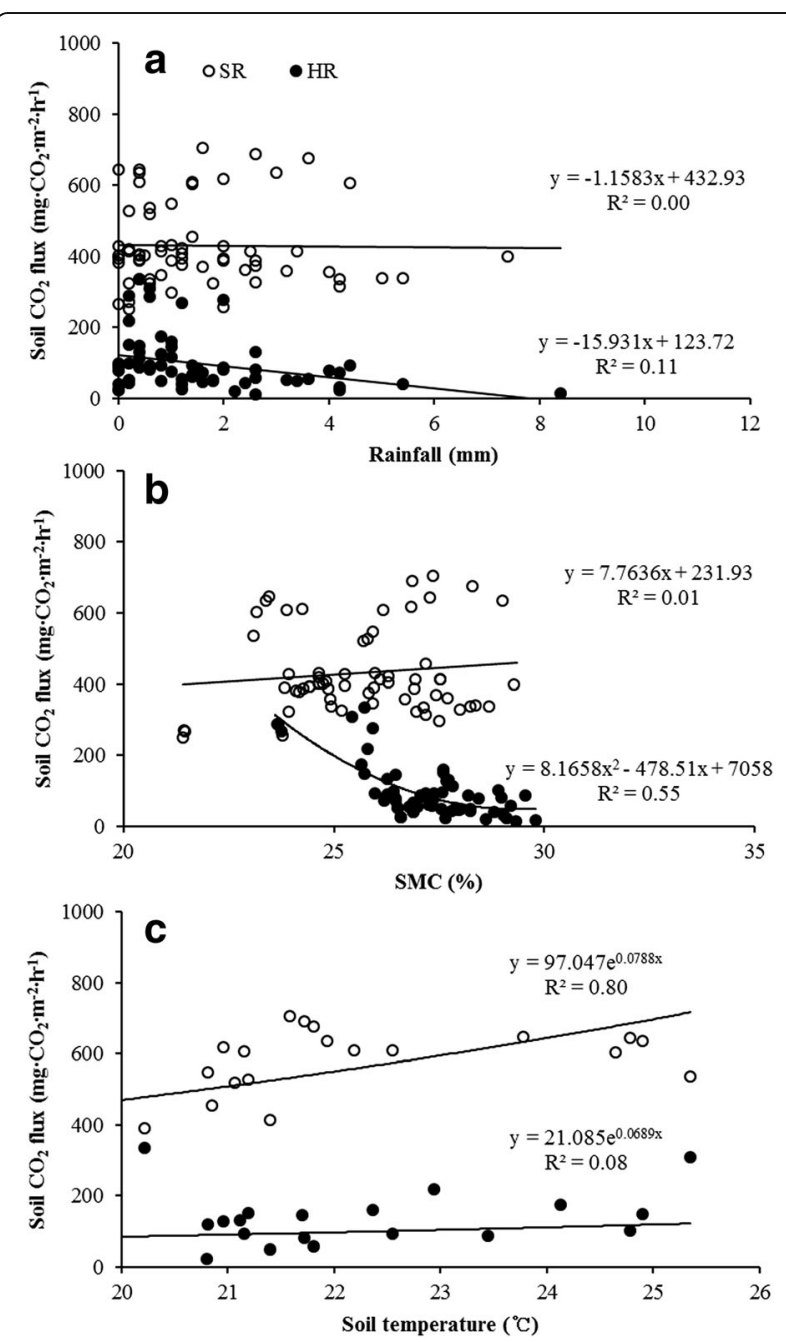

Fig. 6 The relationships between soil respiration (SR) and heterotrophic respiration $(H R)$ with rainfall $(\mathbf{a})$, soil moisture content (b), and soil temperature at 5-cm depth (c) during rainfall event 
rainfall events, was exponentially correlated with SR $\left(R^{2}=0.794\right)$ and $\operatorname{HR}\left(R^{2}=0.6897\right)$.

\section{Conclusions}

This study attempts to understand the changes in soil carbon flux in mountain pastures when a rainfall event occurred. Soil moisture content changed dramatically according to the amount and duration of rainfall in Korean alpine grassland. And it highly affected to change of respiration in soil. Soil moisture content was quickly increased with the rainfall above $5 \mathrm{~mm} \mathrm{~h}^{-1}$. And saturated soil moisture content was observed when precipitation was persisted for more than $5 \mathrm{~h}$ rather than after strong rainfall. In addition, when rainfall events occurred, the SR was increased but the HR was decreased significantly. It was assumed by physical and biochemical effects of rainfall that it reduces the soil porosity and it affected the reduced releasing of $\mathrm{CO}_{2}$ from the soil and respiration rates in soil. Increased soil moisture content which resulted from rainfall events also reduced the HR by inhibiting the respiration of soil microorganisms. However, SR did not show suppression of respiration in the heavy rainfall, and it seems that root has obviously contributed to high respiration in heavy rainfall, but it was affected by quick dry which resulted to depression in respiration under low rainfall. Therefore, the difference of SMC due to rainfall event was causative of a highly fluctuated soil respiration rate in the same soil temperature condition. Therefore, amount and pattern of rainfall needed to be considered in predicting the soil carbon flux of grassland ecosystems for future climate change. These results help to understand the characteristics that rainfall event is a very important controlling factor in the soil carbon flux in grassland ecosystems.

\section{Abbreviations}

HR: Heterotrophic respiration; SMC: Soil moisture content; SR: Soil respiration

\section{Acknowledgements}

Not applicable.

\section{Funding}

This research was supported by "Cooperative Research Program for Agricultural Science \& Technology Development" Rural Development Administration, Republic of Korea (project no.: PJ01001302).

\section{Availability of data and materials}

Please contact the author for data requests.

\section{Authors' contributions}

All authors conducted a survey together during the study period. JSH wrote the manuscript. LSS participated in the design of the study and examined the manuscript. All authors read and approved the final manuscript.

\section{Ethics approval and consent to participate}

Not applicable.

\section{Consent for publication}

Not applicable.

\section{Competing interests}

The authors declare that they have no competing interests.

\section{Publisher's Note}

Springer Nature remains neutral with regard to jurisdictional claims in published maps and institutional affiliations.

\section{Author details}

${ }^{1}$ Department of Biological Science, Konkuk University, Seoul, South Korea. ${ }^{2}$ Division of Ecosystem Service \& Research Planning, National Institute of Ecology, Choongnam, South Korea.

Received: 22 June 2017 Accepted: 27 October 2017

Published online: 17 November 2017

\section{References}

Birch, H. F. (1958). The effect of soil drying on humus decomposition and nitrogen availability. Plant and Soil, 10, 9-31.

Bottner, P. (1985). Response of microbial biomass to alternate moist and dry conditions in a soil incubated with $14 \mathrm{C}$-and $15 \mathrm{~N}$-labelled plant material. Soil Biology and Biochemistry, 17, 329-337.

Chen, H., Shao, M., \& Li, Y. (2008). The characteristics of soil water cycle and water balance on steep grassland under natural and simulated rainfall conditions in the Loess Plateau of China. Journal of Hydrology, 360, 242-251.

Climatological Normals of Korea. (2011). Korea Meteorological Administration. Seoul: Climatological Normals of Korea.

Cole, C. V., Burke, I. C., Parton, W. J., Schimel, D. S., Ojima, D. S., \& Stewart, J. W. B. (1989). Analysis of historical changes in soil fertility and organic matter levels of the North American Great Plains. In Proceedings/the International Conference on Dryland Farming (pp. 436-438).

Davidson, E., Belk, E., \& Boone, R. D. (1998). Soil water content and temperature as independent or confounded factors controlling soil respiration in a temperate mixed hardwood forest. Global Change Biology, 4, 217-227.

Dixon, R., Brown, S., Houghton, R. E. A., Solomon, A. M., Trexler, M. C., \& Wisniewski, J. (1994). Carbon pools and flux of global forest ecosystems. Science (Washington), 4263, 185-189.

Eswaran, H., Van Den Berg, E., \& Reich, P. (1993). Organic carbon in soils of the world. Soil Science Society of America Journal, 57, 192-194.

Fay, P. A., Carlisle, J. D., Knapp, A. K., Blair, J. M., \& Collins, S. L. (2003). Productivity responses to altered rainfall patterns in a C4-dominated grassland. Oecologia, 137, 245-251.

Foley, J. A., DeFries, R., Asner, G. P., Barford, C., Bonan, G., Carpenter, S. R., Chapin, F. S., Coe, M. T., Daily, G. C., Gibbs, H. K., Helkowski, J. H., Holloway, T., Howard, E. A., Kucharik, C. J., Monfreda, C., Patz, J., Prentice, I. C., Ramankutty, N., \& Snyder, P. K. (2005). Global consequences of land use. Science, 309, 570-574.

Gliński, J., \& Stępniewski, W. (1985). Soil aeration and its role for plants. Soil aeration and its role for plants. Boca Raton, Florida: CRC Press. Inc.

Goldewijk, K. K. (2001). Estimating global land use change over the past 300 years: the HYDE database. Global Biogeochemical Cycles, 15, 417-433.

Haas, H. J., Evans, C. E., \& Miles, E. F. (1957). Nitrogen and carbon changes in Great Plains soils as influenced by cropping and soil treatments. In Technical bulletin (p. 1164). Washington, D.C, WC: US Department of Agriculture.

Han, S. Y., \& Kim, D. J. (1993). Studies on the rotation system to forage crop cultivation at the alpine area. Journal of the Korean Society of Grassland and Forage Science, 13, 300-304.

Hanson, P. J., Edwards, N. T., Garten, C. T., \& Andrews, J. A. (2000). Separating root and soil microbial contributions to soil respiration: a review of methods and observations. Biogeochemistry, 48, 115-146.

Houghton, R. A. (1999). The annual net flux of carbon to the atmosphere from changes in land use 1850-1990. Tellus B, 51, 298-313.

Huang, B., \& Nobel, P. S. (1993). Hydraulic conductivity and anatomy along lateral roots of cacti: changes with soil water status. New Phytologist, 123, 499-507.

Hungate, B. A., Holland, E. A., Jackson, R. B., Chapin, F. S., Mooney, H. A., \& Field, C. B. (1997). The fate of carbon in grasslands under carbon dioxide enrichment. Nature, 388, 576-579.

Huxman, T. E., Snyder, K. A., Tissue, D., Leffler, A. J., Ogle, K., Pockman, W. T., Sandquist, D. R., Potts, D. L., \& Schwinning, S. (2004). Precipitation pulses and carbon fluxes in semiarid and arid ecosystems. Oecologia, 141, 254-268.

Lambin, E. F., \& Meyfroidt, P. (2011). Global land use change, economic globalization, and the looming land scarcity. Proceedings of the National Academy of Sciences, 108, 3465-3472. 
Lauenroth, W. K., \& Bradford, J. B. (2009). Ecohydrology of dry regions of the United States: precipitation pulses and intraseasonal drought. Ecohydrology, 2, 173-181.

Lee, X., Wu, H. J., Sigler, J., Oishi, C., \& Siccama, T. (2004). Rapid and transient response of soil respiration to rain. Global Change Biology, 10, 1017-1026.

Liu, X., Wan, S., Su, B., Hui, D., \& Luo, Y. (2002). Response of soil $\mathrm{CO}_{2}$ efflux to water manipulation in a tallgrass prairie ecosystem. Plant and Soil, 240, 213-223.

Meyer, W. B., \& Turner II, B. L. (1994). Changes in land use and land cover: a global perspective (Vol. 4). Cambridge: Cambridge University Press.

Musselman, R. C., \& Fox, D. G. (1991). A review of the role of temperate forests in the global $\mathrm{CO}_{2}$ balance. Journal of the Air \& Waste Management Association $41,798-807$

Noh, T. H., Han, B. H., Kim, J. Y., Lee, M. Y., \& Yoo, K. J. (2013). Actual vegetation and structure of plant community in Daegwallyeong ranch, Gangwon-do (province). Korean Journal of Environment and Ecology, 27, 579-591.

Nosberger, J., Blum, H., \& Fuhrer, J. (2000). In H. F. Hodges (Ed.), Crop ecosystem responses to climatic change: productive grasslands. Climate change and global crop productivity (pp. 271-291). Wallingford: CAB International.

Ohashi, M., Gyokusen, K., \& Saito, A. (2000). Contribution of root respiration to total soil respiration in a Japanese cedar (Cryptomeria Japonica D. Don) artificial forest. Ecological Research, 15, 323-333.

Parton, W. J., Schimel, D. S., Cole, C. V., \& Ojima, D. S. (1987). Analysis of factors controlling soil organic matter levels in Great Plains grasslands. Soil Science Society of America Journal, 51, 1173-1179.

Raich, J. W., \& Schlesinger, W. H. (1992). The global carbon dioxide flux in soil respiration and its relationship to vegetation and climate. Tellus B, 44, 81-99.

Sala, O. E., \& Lauenroth, W. K. (1982). Small rainfall events: an ecological role in semiarid regions. Oecologia, 53, 301-304.

Scurlock, J. M. O., \& Hal, D. O. (1998). The global carbon sink: a grassland perspective. Global Change Biology, 4, 229-233.

Skopp, J., Jawson, M. D., \& Doran, J. W. (1990). Steady-state aerobic microbial activity as a function of soil water content. Soil Science Society of America Journal, 54, 1619-1625.

Sponseller, R. A. (2007). Precipitation pulses and soil $\mathrm{CO}_{2}$ flux in a Sonoran Desert ecosystem. Global Change Biology, 13, 426-436.

Stark, J. M., \& Firestone, M. K. (1995). Mechanisms for soil moisture effects on activity of nitrifying bacteria. Applied and Environmental Microbiology, 61, 218-221.

Steenwerth, K. L., Jackson, L. E., Calderón, F. J., Scow, K. M., \& Rolston, D. E. (2005). Response of microbial community composition and activity in agricultural and grassland soils after a simulated rainfall. Soil Biology and Biochemistry, 37, 2249-2262.

Suh, S. U., Chun, Y. M., Chae, N. Y., Kim, J., Lim, J. H., Yokozawa, M., Lee, M. S., \& LEE, J. S. (2006). A chamber system with automatic opening and closing for continuously measuring soil respiration based on an open-flow dynamic method. Ecological Research, 21, 405-414.

Suseela, V., Conant, R. T., Wallenstein, M. D.. \& Dukes, J. S. (2012). Effects of soil moisture on the temperature sensitivity of heterotrophic respiration vary seasonally in an old-field climate change experiment. Global Change Biology, $18,336-348$.

Tamai, K. (2010). Effects of environmental factors and soil properties on topographic variations of soil respiration. Biogeosciences, 7, 1133-1142.

Trumbore, S. (2000). Age of soil organic matter and soil respiration: radiocarbon constraints on belowground C dynamics. Ecological Applications, 10, 399-411.

White, R. P., Murray, S., Rohweder, M., Prince, S. D., \& Thompson, K. M. (2000). Grassland ecosystems (p. 81). Washington DC: World Resources Institute.

Xu, Z., Tang, S., Xiong, L., Yang, W., Yin, H., Tu, L., Wu, F., Chen, L., \& Tan, B. (2015). Temperature sensitivity of soil respiration in China's forest ecosystems: patterns and controls. Applied Soil Ecology, 93, 105-110.

Yiqi, L., \& Zhou, X. (2010). Soil respiration and the environment. San diego: Academic press.

\section{Submit your next manuscript to BioMed Central and we will help you at every step:}

- We accept pre-submission inquiries

- Our selector tool helps you to find the most relevant journal

- We provide round the clock customer support

- Convenient online submission

- Thorough peer review

- Inclusion in PubMed and all major indexing services

- Maximum visibility for your research

Submit your manuscript at www.biomedcentral.com/submit
Biomed Central 